\title{
Institutional investors and the language of finance: the global metrics of market performance
}

Gordon L Clark, Tessa Hebb, and *Dariusz Wójcik, School of Geography \& the Environment, and *Jesus College, University of Oxford, Mansfield Rd, Oxford OX1 3TB, United Kingdom

Draft: 27 January 2005

\begin{abstract}
With the collapse of the TMT bubble and a number of high-profile scandals of corporate governance around the world, the language of finance is being re-written to include market inefficiency. Not surprisingly, there is an increasing premium on market information national and international. As a consequence, the argument in favour of global standards has gained force, encouraged by new institutions such as the IASB. Co-existence of reporting standards seems a most unlikely prospect just as harmonisation may be less important than convergence to a set of standards deemed to be "best practice" in terms of global financial performance. With the increasing global significance of institutional investors and their portfolio managers, common standards set within well-defined parameters are clearly on the agenda; convergence is the name of the game rather than a tapestry of multi-coloured threads stitched together for the sake of expediency. In this paper, we develop these observations paying particular regard to the interests of institutional investors as well as the burgeoning market for global metrics not just national reporting standards.
\end{abstract}

Keywords. Financial markets, globalization, information, institutional investors, global metrics, portfolio managers

JEL Codes. F36, G15, G23

Acknowledgements. This paper is based on a larger project on institutional investors and global financial markets funded, in part, by a Canadian Social Sciences and Humanities Research Council project at the University of Toronto, drawing upon previous research funded by the European Science Foundation and the UK Economic and Social Research Council. We would like to thank our colleagues for their interest and comments on these projects including Lisa Hagerman, Rob Bauer (ABP), Jamie Salo, Kendra Strauss and Adam Tickell (Bristol). The first-named author also benefited from a conversation on Europe and related topics with Jeffrey Gordon (Columbia). None of the above should be held accountable for the views and opinions expressed herein. 


\section{Introduction}

One way of thinking about global finance is to think of its flows. Every day, huge volumes of traded currencies circumnavigate the globe putting in play the relative value of at least 10 currencies if not the stability of the global economy (Sarno and Taylor 2002). Likewise, portfolio managers trade on home and away stock markets seeking to take advantage of arbitrage opportunities and the more or less efficiency of their "home" market verses other markets. In the world of market flows and inter-market arbitrage, information is at a premium. In some markets, information is largely public in that it is openly disclosed to market participants according to well-established rules and regulations. In other markets, there is a mixture of public and private information derived, in part, from the historical privileges accorded to inside investors as opposed to outside investors. The fact that information is less than ubiquitous and has a price has implications for market efficiency, and the investment performance of portfolio managers (Clark and Wójcik 2003).

Another way of thinking about global finance is to think about its institutions. We could study "public" international institutions such as the Bank for International Settlements, the International Monetary Fund, and the various coordinating national institutions that meet on a regular basis to "manage" financial stability. In this paper, these organisations are hardly ever mentioned except to note that their mandates are less about controlling and regulating the flows of global finance than responding to and coping with the adverse consequences of uncoordinated market action (Cable 1999). In this paper we focus on "private" institutions such as institutional investors and the market for financial services that has mushroomed over the past 40 years or so to dominate the management of global financial assets (Davis and Steil 2001). We also refer to communal institutions that are, in effect, the building blocs of social practice (Pettit 2002) — in this case, modern portfolio theory and its related progeny.

One of the commonly-made observations exploited in this paper is that the theory and practice of finance is based upon information (Wilhelm and Downing 2000). Market agents make trades and plan strategies on the basis of observed market prices. By this logic, information not only greases the wheels of global financial transactions, it also goes to the very heart of the practice of finance that has come to dominate investment management itself. We argue that the language of finance has distinctive market-specific characteristics representing its history in the Anglo-American world. We also argue that the language of finance is a language of practice that privileges minority "outside" shareholders as opposed to majority 
"inside" shareholders (the latter being representative of continental European regimes of accumulation and distribution).

The language of finance revolutionised Anglo-American financial markets, and guides portfolio investment managers as they circle the world looking for investment opportunities. In part, the presumption in favour of portfolio diversification has taken institutional investors to other markets around the world though based upon very different historical circumstances, customs, and conventions (i.e. political economies). One consequence has been the drive to standardise information disclosure in each and every market against various public and private templates, including those developed by the International Accounting Standards Board. Another consequence, however, has been to re-conceptualise the role and status of portfolio investors especially as regards their role in affecting the governance of major corporations (Clark and Hebb 2004).

In fact, it could be argued that the object of institutional investment managers is what Chandler (1990) referred to in the US context as managerial capitalism and what we would refer to as "insider" capitalism (see also Roe 1994 on strong managers and weak owners etc). To the extent that insider or managerial capitalism is the object of institutional investors, their goal is to wring-out from those institutions the value held by managers and the untraded benefits that flow through the relationships between insiders as opposed to the property rights of outsiders. If this was the guiding logic for institutional investment in Anglo-American markets over the past 30 years or so it has become the motive force for corporate restructuring in continental Europe at the turn of the 21 st century (Clark and Wójcik 2005a). Understanding how and why this came to pass as well as the response of national champions to these pressures is another contribution of the paper (compare with Zorn et al. 2004 on the US firm).

Like Lo (2004), we argue that the language of finance seems to have come to a dead end. The TMT bubble and the crisis of confidence in corporate governance have conspired to undercut the hegemony of the language of finance while simultaneously putting in play a burgeoning market for information that goes well beyond the parameters set by modern portfolio theory. Even those most committed to the theory of efficient markets have conceded that the intellectual scaffolding underpinning the language of finance hardly ever works as expected or desired (compare Fama 1970 with Fama and French 2005). Inevitably, investment managers have sought alternative routes for extracting value from financial markets around 
the world. One way of doing so requires a better appreciation of the empirical relationships that might be found between corporate governance and market value (however both are measured and described). This empirical world is inevitably and fundamentally information intensive. But it now goes well beyond the reference points of finance theory that held sway for a couple of generations (for example, Ho and Lee 2004).

As institutional investors take seriously their global investment responsibilities the information required to make judgments about those responsibilities has begun to take into account a variety of issues previously excluded including social and environmental concerns. In a sense, the failure of the language of finance has given the market for information a remarkable boost and with it the opportunity to establish new metrics for judging the performance of global corporations over the short-run and the long-run (Clark and Hebb 2005). Institutional investors have sought to expand the metrics used to judge performance and have played crucial roles in fostering the development of new intermediaries providing this kind of information (Salo 2005). All this suggests that conventional metrics such as those conceived in finance theory and those proposed by the International Accounting Standards Board are now necessary but not sufficient for investment practice.

The paper is organised in the following manner. The next section provides a potted history of the rise and fall of managerial capitalism. Throughout we refer to the Anglo-American world with the contrast drawn to continental Europe -- a useful way of sustaining our argument. We then move on to the intellectual roots of finance noting its principles as well as its implications for institutional investors. Thereafter, we argue that this language became hegemonic spreading around the globe and in particular being a means of valuing European institutions. This leads to an analysis of the burgeoning market for information in the face of acknowledged problems with the language of finance noting its implications for national and international investment practices. In general, our strategy in preparing this paper has been to identify the "big" issues rather than reporting original results. In the interests of setting-out our argument, we have eschewed technical precision in favour of principles and practices. As a result, the paper is designed to set a framework for research and a means of understanding what follows. 


\section{Recent history}

According to Chandler (1990), by the early years of the $20^{\text {th }}$ century much of the US economy had assumed the organizational form of managerial capitalism that was to dominate the century. For Chandler, centralised corporate administration combined with vertical integration was the operative solution to the competitive pressures associated with the geographical scope of the continental economy. Whereas financiers played crucial roles in the formation of conglomerates, Chandler argued that their significance was quickly discounted as the expanding scope and scale of corporate activities empowered managerial elites. He compared US managerial capitalism with other forms of capitalism in developed economies distinguishing, for example, between Britain (personal capitalism) and Germany (co-operative capitalism). Most importantly, he suggested that public distrust of banking over the $19^{\text {th }}$ century and early $20^{\text {th }}$ century was such that the US finance industry remained decentralized, fragmented, and the fiefdom of individuals rather than national institutions (in contrast to Germany and Britain). ${ }^{1}$

After the great depression and the Second World War, a large portion of financial assets were locked in governments, nationalised industries, and large corporations. Moreover, the mobilization of financial assets for the Second World War had effectively re-made the US into the international bank (and creditor) of last resort. In this respect, macroeconomic identities like the components of real national income rather than the structure and performance of stock markets dominated economic calculation. The Keynesian-cumneoclassical synthesis which was to hold sway in economic textbooks for nearly forty years hardly ever mentioned finance except when discussing the causes and consequences of the 1929 crash and the coordination of international trade. By the early 1980s, however, the financial system and stock markets had become very important in Anglo-American economies: pension funds were growing fast in terms of the volume of net contributions and accumulated assets, and; the deregulation of the banking industry during the 1970s and 1980s combined with recurrent waves of mergers and acquisitions in manufacturing industries prompted the growth of new kinds of financial intermediaries as well as the demand for new kinds of financial products (Allen and Gale 2000).

\footnotetext{
1\% Recent research on the "varieties of capitalism" has resuscitated this kind of characterization, encouraged by notions such as path dependence and systems integration (see generally Hall and Soskice 2001). As we shall see, however, our argument is not entirely sympathetic to this literature in that we argue theoretically and empirically that the past is not ipso facto the future - all kinds of economic agents have an interest in making the future in their own image (see Clark and Wójcik 2005b).
} 
Over the second half of the $20^{\text {th }}$ century, in the Anglo-American world managerial capitalism was overtaken by financial capitalism. New kinds of national and global institutions were formed with access to financial resources far-surpassing those available to hitherto largely self-financing manufacturing corporations. Not only were these institutions increasingly important for corporate restructuring on behalf of ambitious corporate raiders, they had become important owners of corporate stocks and bonds in their own right even if their individual holdings were quite small (compared to the German practice of financial institutions holding large blocks of preferential voting stocks in closely-related companies). Most importantly, these financial institutions became increasingly active agents in hostile mergers and acquisitions funding, in effect, the market for corporate control (Jensen 1993). Instead of supporting entrenched corporate managers, financial institutions focused upon releasing corporate value to stock owners-an organizing principle that has taken many forms including "corporate engagement" in the aftermath of the TMT bubble and corporate governance scandals (see Clark and Hebb 2004).

Underpinning the emerging power of financial capitalism has been a set of rules, regulations, and practices as well as iconic glass and steel office blocks. For example, Anglo-American pension funds are governed by the principle of fiduciary duty inherited common law of trust albeit formalised in statute and regulation (Clark 2005). Importantly, regulations requiring the full funding of expected obligations against market value combined with a required (if not always enforced) separation between the financial interests of the plan sponsor or sponsors and plan beneficiaries created large pools of "independent" investment capital. By contrast, the book reserve system of pension funding left German pensions plans largely "underfunded" and hostage to the interests of corporate managers in adding to physical plant and equipment rather than the interests of employees in investing those assets nationally and internationally (Clark 2003a). Further more, the enormous growth in pension fund assets combined with an increasing concern for the cost-efficient administration and management of pension fund assets encouraged the development of a global financial services industry centred on the Anglo-American world whose principal clients are neither corporations nor governments (Hayes 1993). ${ }^{2}$

2 . These developments have been described in various ways. Most importantly, Clark (2000) suggested the phrase "pension fund capitalism" while Hawley and Williams (2000) referred to these developments as 
The rules governing the theory and practice of investment have also been transformed over the past 50 years. Bernstein (1992) traced the recent origins of the theory of finance to Markowitz's (1952) seminal paper on "portfolio selection". That paper was one of a small number of related papers published around that time that provided both the conceptual apparatus for valuing stocks and the rudiments for optimal portfolio design (see also Roy 1950). Bernstein noted that Markowitz's paper was not an immediate citation classic. It was to remain unknown to most academics and practitioners for some decades before coming to the attention of new generations of scholars working on option pricing and the capital asset pricing model. In this regard, it set the terms of reference for the application of advanced mathematical methods to the analysis of risk assuming efficient financial markets. Academic significance is one thing (though highly desirable). Arguably more important was the realisation twenty-five years or so on that Markowitz's paper provided a recipe for investment practice for the "new" institutions of financial capitalism. There has been a close even reciprocal relationship between academic research on these issues and the growth of the sponsoring investment institutions. ${ }^{3}$

For many years, fiduciaries had been governed by the so-called "constrained" prudent man rule. By this interpretation of trustee responsibility, each and every investment was to be evaluated with respect to expected risk and those investments deemed too "risky" were to be avoided as a matter of principle (Gordon 1987). One of the implications of Markowitz's paper on portfolio design and subsequent developments in portfolio investment theory was the recognition that the risk of any investment or asset class should be assessed against the risk profile of the whole portfolio. Moreover, given the demonstrable positive relationship between risk and return, there were objective reasons to take on risk in relation to desired rates of return. The principles of portfolio diversification combined with the removal of implicit and explicit restrictions on investment in certain asset classes and jurisdictions revolutionized financial markets. A global marketplace has developed for financial

\footnotetext{
"fiduciary capitalism" (compare with Drucker 1995 where he first raised the prospect of "pension fund socialism").

$3 \%$. This can be thought instrumental in that academic research is, sometimes, applied to pricing stocks and modelling market patterns. But we would contend that there is another less instrumental side to the story. Once we focus upon market institutions and behaviour, there are important conceptual puzzles to be resolved that go to the heart of social science - such as the predictability of behaviour over time and space in a global economy (Shiller 2003).
} 
innovation-key features of modern investment management have extended asset allocation from stocks and bonds to alternative investments such as hedge funds, venture capital, and the like. ${ }^{4}$

\section{A universal language}

At the core of Anglo-American economies are the institutions of finance capital; this is a structural feature of modern economies carrying with it particular forms of behaviour and social practice (Beunza and Stark 2004). If the early years of the 20th century saw the rise of a corporate elite claiming power at the very centre of their organisations, by the end of the $20^{\text {th }}$ century a new elite had been born operating within and without the modern corporation using the tools of finance to claim control of corporate capitalism. This is a story commonly told about Anglo-American economies. But it is a story increasingly familiar to continental European economies that might otherwise claim a heritage and mode of corporate organisation quite different from their Anglo-American relations, even if a great deal of academic research has been devoted justifying the co-existence of very different systems of capitalist accumulation in the face of the emerging power of global financial institutions and their financial engineers. ${ }^{5}$

Here, we take the argument in a slightly different direction emphasising the practice of finance-its logic, rules, and types of calculations made about risk and return that have come to represent not only the prospects of individual corporations but also the prospects of whole industries and indeed whole countries (Hebb and Wójcik 2005). One of the most important differences between the finance capitalism of the 21 st century and the financiers of the late 19th and early 20th centuries is the fact that finance is now an industry populated by many thousands of skilled employees who share, more often than not, a common language about the theory and practice of finance. Whether located in New York, Tokyo, London or Frankfurt and whether employed by Goldman Sachs, the Bank of Tokyo, or Deutsche Bank, they all

\footnotetext{
4. We should take care not to exaggerate the innovation potential of financial markets. Just as the "efficient markets hypothesis" prompted the development of one kind of market-pricing theory, it also denied the relevance of other kinds of market-pricing theories. There is a cost to borne from the hegemony of one kind of theory - innovation can be stifled in these circumstances (witness the resistance to non-Bayesian notions of probability) whatever the virtues of competition (compare Baumol 2002).

\%. See, for example, Dore (2000) and O'Sullivan (2000). An institutional perspective that is sensitive to history and geography is an important element in any comprehensive treatment of the development of twentieth-century capitalism; a common epistemological commitment shared by those working on comparative corporate governance and the geography of finance (see also Hopt et al. 1998 and Clark and Wójcik 2005a).
} 
know about the capital asset pricing model, the Black-Scholes option-pricing theorem, the Sharpe ratio and the information ratio etc. (elementary reference points in any discussion about modern investment theory). This has had significant implications for understanding the spread of Anglo-American financial practice to distant shores just as it has significant implications for understanding the standards set by institutions such as the International Accounting Standards Board.

The language of finance is built upon three axioms derived from modern portfolio theory (Houthakker and Williamson 1996). These axioms are essential for the whole edifice: first, financial markets are efficient in the sense that they embody all available information relevant to the formation of prices; second, market arbitrage inevitably drives-out market imperfections such that market inefficiency is idiosyncratic rather than systematic; and third, market behaviour is rational in the sense that rational agents dominate irrational agents through the exploitation of the latter by the former. Of course, the TMT bubble and the systematic misleading of the market by those with a stake in market speculation have challenged the plausibility of these axioms (Clark et al. 2004; Shiller 2000). Furthermore, the application of the results of experimental psychology to understanding market behaviour has brought to light what appear to be systematic anomalies undercutting the hegemony of the rational actor model (see Hilton 2003 on the implications of these findings for the study of financial markets). Not withstanding the significance of these empirical objections, the theory of efficient markets stands as a reference point uniting the practitioners of finance (Lo 2004).

The language of finance is also built upon three stylised facts about the world: first, as core markets become ever more efficient, opportunities for higher rates return are to be found in markets that are relatively less efficient; second, in a world of economic globalisation, competition is more about industries than countries suggesting that investment inevitably flows to lower-priced sites of production; and third, there is a premium to be had for those capable of identifying imperfections and being able to move on to new opportunities as the rest of the market catches-up. One does not have to be a believer in the "strong" version of market efficiency to agree that these stylised facts about the world are at least one plausible scenario for the future. Each is, of course, quite contentious especially in terms of the claimed declining significance of national borders. Significantly, the combination of axioms and stylised facts provides both a recipe for short-term and long-term investment strategy recognised as such by the Goldman Sachs textbook on investment management as well as the 
Goldman Sachs report on global growth prospects over the next 50 years (see, respectively, Litterman et al. 2003 and Wilson and Purushothaman 2003).

The language of finance as a shared language of practice is also built around the education of financial analysts. Not only is there virtually a common finance curriculum around the world, finance has become a core component of MBA education. Furthermore, when staffing finance functions institutions often sort amongst applicants according to the extent to which shared education is likely to reinforce the competence of existing teams. In these institutions, there is often an implicit or explicit hierarchy of authority calibrated according to finance-related skills. Just as importantly, clients have come to expect financial service providers to sell their services according to the expertise assumed embodied in certain types of people (their training and education). In many cases, clients do not understand modern portfolio theory. But they are convinced that adherence to its axioms is a measure of quality differentiating between competing financial service providers. Most importantly, the language of finance is almost always the language of ex-post legitimisation - the reference point used to explain how and why investment strategies may or may not have worked as expected.

The language of finance as a shared language of practice has three qualities. First, it is a comprehensive language, providing a recipe book for decision-making down through hierarchies of tasks and skills. It has been internalised into everyday practice such that it is a point of reference for the execution of tasks in large and small organisations (Clark and Thrift 2004). Furthermore, it is the reference language for those in authority; to rank-order competing claims for action while excluding those claims that do not fit either the parameters or indeed the shared world-view that underpins these terms. At the limit, the language of finance is exclusive of other views about the world: amongst its adherents, it promotes homogeneous cultures of practice and homogeneous market expectations.

Most remarkably, the language of finance is first and foremost English. Whereas 10 or 15 years ago dictionaries of translated financial terms proliferated, as new generations of financial analysts have joined global financial institutions English has become the reference language for texts uniting terms and functions. Dictionaries have become more complex, more detailed, and more technical as opposed to conceptual. A commitment to English as the 
lingua franca of finance has made this possible. ${ }^{6}$ By contrast, local languages have remained the languages for marketing and client relationships although, even in these circumstances, English terms have found their way into discussions with clients about the latest innovations in financial engineering. This being the case, the language of finance may be thought hegemonic, in ways similar to those Power (2004) attributes to related concepts such as 'enterprise risk management'.

\section{Portfolio design and investment management}

Like many others who have sought a break point in the post-war record of economic growth, Clowes (2000) identified 1973 as the moment where the balance of power shifted in favour of investment management firms and away from bank trust departments. ${ }^{7}$ He suggested that these new institutions had two related goals: achieving higher rates of return in relation to accepted benchmarks; and rates of return in excess of that measured by a stock market index such as the S\&P500. He contended that bank trust departments offering similar investment functions were often more risk-averse and unwilling to embrace the new language of finance. In any event, by his account at least, bank trust departments clung to their traditional relationships with large manufacturing corporations failing to respond to the emergence of new kinds of financial institutions shorn of alliances with those kinds of corporations. Similar banking-corporate relationships were to hold sway in much of continental Europe through to the end of the 1990s (at least).

With a recipe for portfolio design and a rapidly growing volume of assets to be invested, investment management became a highly competitive and structured exercise. Instead of placing large tranches of assets with selected stocks underpinned by personal or long-term cross-institution relationships with target companies, portfolio designers eschewed past relationships in favour of diversifying investment across the market of traded securities. Of course, there were constraints (as there remain constraints) on this kind of investment

\footnotetext{
6. Reinforcing our point was the announcement in late 2004 that the Deutsche Börse would adopt English as the "official" language of the Frankfurt market, to be used in all shareholder communications, trading, and announcements. No doubt this announcement was spurred by the take-over offer for the London Stock Exchange. Equally, it reasonably reflects the actual practice of the global financial industry.

7\%. In much of the academic literature, 1973 is seen as the end of the post-war "golden era" and the emergence of a new regime of accumulation commonly referred to as post-Fordism (see Amin 1994). We are agnostic on this notion of a binary structural transformation while agreeing with Clowes that the rise of financial capitalism and the decline of managerial capitalism can be conveniently captured by a date such as 1973 - the point where two trends cross over one-another (see also Webber and Rigby 1996).
} 
strategy. If expected performance is benchmarked against a market index, assets must be distributed such that stocks that dominate the index are appropriately represented in the portfolio. Otherwise, there is a real risk of under-performing the market. In any event, the smaller the market capitalisation of a company, the lower its market liquidity and consequently the higher the risk of being trapped holding that stock relative to other opportunities. As the investment management industry matured, the practise of investment became subject to scrutiny by peers and clients alike utilizing the tools of the new orthodoxy (Litterman et al. 2003).

To illustrate, assume a client has $£ 1$ billion in assets to be invested and assume that the client faces the prospect of a net inflow of contributions year-on-year over the foreseeable future. If we also assume the client underwrites the expected value of benefits or in some way provides a capital guarantee, risk and return over the short-run and long run are crucial metrics in any investment decision-making process. By convention, three types of decisions are made (in the following order): the allocation of assets to different asset classes, the allocation of assets to specific types of investment products or strategies within asset classes, and the allocation of those assets to financial service providers (Campbell and Viceira 2002). We also assume, for the moment, that assets are allocated only to domestic stocks and bonds (as was certainly the case 30 years ago). If there is a 50/50 split of assets between stocks and bonds, Figure 1 represents a common model of asset allocation to traded corporate securities: the allocation of assets is weighted towards the largest capitalised stocks. ${ }^{8}$ This kind of logic works even if we segment the stock market into large cap, medium cap, and small cap components (with their own benchmarks for assessing risk and return).

Also assume total market capitalisation is $£ 1$ trillion and that the average large institutional investor has $£ 1$ billion to invest. This suggests the following. First, by spreading assets widely across the market (subject to the constraints noted above) the capacity of such institutional investors to monitor the performance of individual stocks is very limited. If we assume, in any event, that monitoring performance of individual stocks is expensive for any investor, this function is likely delegated to investment managers in accordance with the investment mandate. Second, by spreading assets across the market, few institutional investors will own a significant portion of any stock. Not withstanding the allocation of assets

\%. For a useful analysis of this type of simple formula for asset allocation, and its consequences for investment returns comparing 1987 with 2004 see Ambachtsheer (2004). 
by market capitalisation, only the largest institutional investors are likely to hold more than 200 basis points of any traded company security. The average holding is likely to be trivial (in relation to the outstanding stock). Third, by spreading assets across the market, institutional investors inevitably rely upon the market for pricing the value of traded securities-in turn, the pricing of any market security relies upon investors responding to positive and negative market signals as to its current and expected value. Since information is very expensive if sought for the entire portfolio, the cheapest strategy is to trade on publicly available information (Davis and Steil 2001).

By this logic, the integrity of market information is an essential ingredient in the performance of investment managers and for the performance of entire securities' market. If information were private, if it flowed first to large shareholders and then was distributed to the market after its meaning had been digested, there would be enormous advantages in being an "insider" as opposed to an "outsider". It is hard to imagine how the recipe for portfolio design owed to the pioneers of modern financial theory could survive such a harsh reality. Not only would market pricing be thoroughly distrusted, the rebalancing of market portfolios would always lag the real state of play in the company stock that made-up those portfolios. Enormous attention would be focused upon the largest capitalised stocks leaving behind even medium sized stocks to fend for themselves. In such circumstances, the stock market could shrink in terms of the numbers of listed companies and the volume of transactions. This is one way of accounting for the relatively concentrated structure of most continental European stock markets and, by contrast, the growth of Anglo-American stock markets over the past 30 years or so. ${ }^{9}$

Opportunism inside and outside of the market is a real threat to its integrity. The history of market information in the Anglo-American world can be written as a history of increasing regulation as to the desired nature and volume of publicly available information. This trend accelerated in the years following the 1929 stock market crash and the great depression (as many aspects of the economy were brought into the ambit of national regulation). More significantly, perhaps, after 1970 the US Securities Exchange Commission (SEC) brought forth a string of regulations broadening the scope and timeliness of information disclosure

$\%$ Of course, the growth and development of Anglo-American stock markets is also due to the inflow of financial assets from funded pension plans prompting more efficient systems of capital allocation and, at the limit, higher rates of real economic growth (Davis and $\mathrm{Hu} 2005$ ) 
enhancing the information content of market prices and thereby promoting market efficiency. Underpinning these regulations have been the related disclosure rules and regulations of professional bodies such as the Financial Accounting Standards Board (FASB). Whether cause or effect, public and private regulation of market disclosure has provided US capital markets sufficient third-party information to make portfolio investment a viable and expanding industry. Not surprisingly, these types of rules and regulations have been emulated in other Anglo-American jurisdictions sharing a similar commitment to market efficiency. Even the European Union has come to believe that the quality and quantity of information disclosure are essential ingredients for the long-term development of the EU economy.

However, it would be misleading to suggest that the Anglo-American regime of information disclosure has been without fault. On one hand, the political vulnerability of FASB on the disclosure and market pricing of stock options was a contributing factor to the "irrational exuberance" of the late 1990s affecting all developed stock markets (Shiller 2000). As well, the common practice of counting investment income from pension assets as corporate income suggests that there remains a political economy of market efficiency never far from the surface. $^{10}$ On the other hand, the volume of disclosure has been such that a market for information processing and valuation has developed matching the interests of the largest institutional investors. Ironically, because of the cost of processing information smaller investors have been sidelined in the market for information, being reliant upon the free-to-air, cable, and print media and all their foibles with respect to the competition for market share and the like (see Clark et al. 2004). In these circumstances, many of the largest institutional investors have sought to exploit the enormous volume of public information believing that superior computing capacity and analytical routines allows for the identification of arbitrage opportunities that go unrecognised in the day-to-day flow of information.

\footnotetext{
${ }^{10} \%$ The rules and regulations governing the disclosure of pension assets and liabilities have varied greatly between Anglo-American jurisdictions and between those countries and continental Europe (see generally Clark 2003a). Just as income on pension plan assets have been counted as corporate income in the US, the rules regarding the disclosure of current and expected pension plan shortfalls have been opaque to many financial market institutions. For all the sophistication in reporting on these issues by specialists, governments and accounting standard institutions have been reluctant to "come clean" on these issues - there is an interesting story to be written on the origins of these very different reporting policies and their implications for estimating current and expected liabilities (Arnott 2004).
} 


\section{On to the rest of the world}

Institutional investors have come to dominate Anglo-American stock markets, and through them the nature and practice of corporate governance especially amongst the largest firms. They are representative of a new form of capitalism one where financial institutions are privileged over production and the financial circumstances of the investing middle-class flows directly into macroeconomic indicators. From 1973, the flow of assets into financial markets became a virtual tidal wave. For example, over the 1990s pension fund assets in Canada, the UK, and the US grew from (respectively) $31 \%, 55 \%$ and $47 \%$ of GDP in 1991 to $48 \%, 66 \%$ and $63 \%$ of GDP in 2001 (Table 1). Even allowing for the effects of the bubble economy, it is clear that the financial foundations of these economies are very different than their European counterparts (Chan-Lau 2004).

Institutional investors have sought to extract stock value from incumbent managers and their relationships with other groups inside and outside of the corporation. There has been widespread debate about this strategy, recognising that the long-term growth of large corporations may require short-term sacrifice in the terms of less than optimal earnings and stock price value. Equally, it has become an article of faith amongst many academic and industry analysts that corporations are a "club" for a well-paid but under-performing corporate elites. It is clear, whatever the merits of each argument, in making corporate elites the object of institutional investor strategy the future of many firms and industries have become issues of market speculation. Furthermore, as institutional investors have broadened their geographical scope, this kind of investment strategy has been applied to other kinds of countries and their institutional systems. Cross-market information on corporate performance, assets and liabilities has become essential ingredients in the process of relative valuation. In this regard, the demand for common reporting practices has been part and parcel of the emerging global market for corporate control.

The future of capitalism has also become the object of investment decision-making. Whereas focus upon the firms of the S\&P500 and the FTSE100 is often an exercise in re-assigning corporate value from managers (income) to owners (stock price value), institutional investors have also sought to anticipate the next frontier and the next set of market opportunities. It is arguable that the TMT bubble was an extreme instance of this process of looking forward. But it is characteristic of financial institutions to anticipate the creation of value especially in circumstances where there are high potential pay-offs compared to the hard graft associated 
with extracting value from mergers and acquisitions. In fact, it is arguable that AngloAmerican financial markets are so efficient that only those institutions with the biggest investment in data-processing technology, talent, and organisational capacity are able to systematically add value. Even in the best of circumstances, relatively low expected rates of return and the squeeze on the equity premium suggest that Anglo-American financial markets have become difficult environments in which to add value (and claim a premium on fees).

In this context, institutional investors have moved towards either information intensive or relationship intensive sectors like hedge funds, venture capital, and related forms of alternative investment. Capital-intensive quantitative analysis of market information and patterns has become big business. Equally, fleet-of-foot investment in areas outside the core competence of most market agents has also become an important refuge from low rates of return in conventional markets. And yet, bulge-bracket bureaucratic monsters are not nearly as adept as boutique investment firms and partnerships in making-value in these circumstances. One consequence has been a shift of geographical focus from an overwhelming concentration upon Anglo-American markets to a renewed interest in the rest of the world. All kinds of investment strategies have been deployed, including conventional portfolio investment in continental European stock markets and private placements in China. The tension apparent in these strategies is a tension between information intensive data processing (portfolio investment) and third-party relationship management (growth based strategies in far-off markets). If executed efficiently, the costs of the former are far lower than the costs of the latter.

Using many of the same theories and investment strategies honed in Anglo-American markets, institutional investors have come to European markets to find value. In the short run, investment houses have treated European markets "as if" they were amenable to these types of methods and techniques. So, for example, investment firms have built virtual investment portfolios across Europe focusing upon firms and industries rather than firms and countries. Here, the European single market has been taken as the current and future reference point for information-intensive capital market investment strategy. Likewise, active investors have taken larger stakes in local firms hoping to precipitate corporate restructuring, mergers and acquisitions on the scale experienced in Anglo-American markets (Clark and Wójcik 2003). National governments have been resistant, however, to the idea of "putting in play" their national champions; not withstanding lower rates of economic growth in much of continental 
Europe over the past few decades, nation-states have been, more often than not, defensive in terms of the European Commission's campaign to accelerate capital and labour market integration. Nevertheless, there are high fees to be had and potential windfall profits to be gained by anticipating the pricing of changes in past relationships.

It would be misleading to imagine that European stock market inefficiency combined with nation-state defensiveness has stymied global investment managers in their attempts to manage portfolios across Europe. Quite the contrary. Waves of new entrants into the European financial services market have empowered somnambulant local investors while giving new firms and new industries a chance to break into financial markets that were otherwise closed to outsiders (Clark and Wójcik 2005b). Furthermore, global investments managers have taken deliberate aim at local and national banking institutions drawing on their experience in the Anglo-American world to attack the nexus between finance and corporate capitalism. Based in London, but drawing upon financial resources and talent from across the world, these institutions represent for many European academic commentators the new (and threatening) world of financialization (see Clark 2003b in response to Engelen 2003).

Anglo-American financial institutions have sought information and data resources consistent with their experience and investment philosophies. This has prompted the growth of private information and corporate ratings agencies, as well as a drive within the European Commission to encourage European adoption of international financial accounting standards consistent with the needs of global portfolio investment managers. As information has become more readily available across markets built upon accepted metrics, portfolio managers have used their data processing capacities to exploit hidden market inefficiencies. In part, this has forced "insiders" to act more like "outsiders" in that their own investment strategies have come to replicate rival Anglo-American corporations rather than reinforcing practices associated with bank-based insider capitalism. By discounting cross-holdings, old loyalties have been put in play in response to the actions of global financial players (Wójcik 2004).

Here lies, of course, one of the objections to the increasing role of portfolio managers in continental Europe. Not only is continental capitalism the object of portfolio managers, the language of finance is the language of shareholder capitalism rather than continental stakeholder capitalism. This has significant implications for the status of the various classes 
of corporate stockowners and bondholders, while discounting the union, community, and regional alliances that have traditionally underpinned industrial corporations. In effect, stakeholder capitalism gave these groups a legitimate voice in the affairs of the corporation. By contrast, the language of finance empowers portfolio managers located outside of the region (and often outside the nation-state) to act on behalf of "owners" who have little commitment to the welfare of those affected by corporate restructuring, mergers and acquisitions etc. In this respect, the language of finance is a language that excludes traditional stakeholders from "governing" the corporation (Dore 2000).

For critics of financialization, the language of finance is all about the putative global hegemony of Anglo-American institutions and practices affecting the economy, society, and culture (Jameson 1997). If there is regret about the passing of an era, there is also resistance to the claims of privilege of the new global financial elites relative to those pushed aside by the imperatives of portfolio management.

\section{Metrics of the global marketplace}

We have suggested that the entry of Anglo-American financial institutions into continental Europe is best understood as an instance of pricing insider capitalism. In this respect it is not unlike the experience of Anglo-American countries over the past 35 years or so even if it comes relatively late in terms of European experience. Inevitably, this kind of value investing is closely associated with the quality and quantity of the available information. Assessing investment opportunities requires detailed disclosure especially if value is to be wrung-out of firms in order to pay for the costs of acquisition. Just as importantly, growth or momentum investment strategies make strong assumptions about the integrity of market prices. On one hand, there is a premium on due diligence. On the other hand, there is a premium on data processing. Not surprisingly, there are strong pressures for convergence in terms of the rules and regulations governing disclosure of market-sensitive information around the world.

Even so, the TMT bubble precipitated a crisis of confidence in Anglo-American financial markets and, by extension, confidence in the theory of finance honed and articulated over the second half of the 20th century (Lo 2004). The basic premise underpinning the TMT bubble was the emergence of a "new economy" based on technology-driven labour productivity and new forms of industry and organisation. As speculation took over stock-by-stock valuation, companies like Microsoft claimed an increasing share of total market capitalisation being, at 
one point, valued more than half a dozen of the largest industrial corporations including GE, GM, Ford, etc. Many in the market believed there was a free ride to be had on the momentum of the market subject to claimed superior techniques of market timing, entry and exit. At a height of the bubble, advocates of the new economy peddled rosy forecasts of unending growth and a Dow-Jones Industrial Index of 36,000. Although there were some analysts, at the time, who suggested that the bubble would collapse, it is clear that neither market prices nor the language of finance provided adequate reference points for attributing "value" to firms and industries. ${ }^{11}$

Much has been written about the consequences of the TMT bubble. We do not intend to go over well-trodden ground. But it is worth emphasising that at the height of the bubble, AngloAmerican markets attracted enormous inflows of capital particularly from European and Asian investors seeking their share of the new economy. The assumed integrity of market prices combined with widespread confidence in American financial accounting practices and regulations gave investors a false sense of security. And underpinning this confidence was confidence in the language of finance which is, in so many respects, a home-grown institution built upon the success of Anglo-American markets over the past few decades. It was common to see investment company "roadshows" in continental Europe and East Asia dominated by young American analysts featured as knowing representatives of the new economy. They were perceived to be representatives of a world of finance far superior to that indigenous. By contrast, the future of non-Anglo-American markets seemed in doubt.

The collapse of the bubble and the crisis of confidence in corporate governance prompted significant legislative and regulatory responses (Coffee 2003; Gordon 2003). Indeed, it could be argued that the resulting Sarbanes-Oxley Act on corporate disclosure standards reestablished American standards of corporate governance as the global market leader. Further more, the current valuation of stock options, so often disputed through the 1990s run-up in American markets, has been part of the reform process (not withstanding continuing objections from Silicon Valley). These initiatives have focused on the integrity of disclosure including the nature, volume, and certification of the quality of market-sensitive information. Significantly, Sarbanes-Oxley and related reforms through FASB were concerned to reassure

\footnotetext{
11\% In fact, Dale (2004) argues that "over confidence" in the metrics of market valuation combined with an inability or unwillingness to recognize "discrepancies" in market pricing is characteristic of all speculative bubbles. His research focused on the South Sea bubble, drawing instructive lessons and commonalities with the TMT bubble.
} 
national and international investors of the integrity of market signals as expressed through relative pricing even if there have been doubts about the practical value of the language of finance in the real-world. It remains, nonetheless, a widely accepted reference point for “explaining” if not practicing investment (Zingales 2000).

However, investors have sought other kinds of metrics not so obviously derived from the language of finance. Most importantly, ratings firms based upon scoring corporate governance have discovered a large and growing market amongst institutional investors. In part, institutional investors use these ratings firms to synthesise and sort the available information thereby circumventing the heavy costs associated with making sense of the avalanche of information disclosed. But, as well, recognising the limitations of market prices, there has been growing interest in empirical relationships rather than theoretical logic. For example, institutional investors have sought information about the relationship between the measured quality of corporate governance, long-term performance, and market value. Further more, there has been increasing interest in the geography of finance in that the scoring of governance practices has had a significant comparative component-using the metrics to evaluate firms in their home jurisdictions against the standards now expected by global investors (Wójcik et al. 2004).

The market for metrics has become highly differentiated over a short period of time (see generally Salo 2005). For example, some institutional investors seek quite narrow metrics based upon the constitution of corporate boards of directors and the process whereby disclosed information is certified. Some institutional investors have extended the range of metrics on the assumption that the formal constitution of the board of directors need not provide adequate information about the likely performance of the company over the longer term. In fact, some ratings companies have sought metrics on the performance of boards themselves arguing that they may be able to identify poor-performing boards before a crisis in the reported performance of the company. Some ratings companies have relatively few indicators amenable to quantitative analysis. Other ratings companies use enormous databases, combining quantitative and qualitative information gleaned from company reports and detailed interviews sensitive to the jurisdiction of incorporation. ${ }^{12}$ By taking seriously

\footnotetext{
$12 \%$ Some companies are entirely focused on public information assuming that this is what moves markets. Other agencies are focused on "inside" information assuming that public information is fully priced even if not always fully used. Yet other agencies are entirely quantitative while others are entirely qualitative. In play are very
} 
jurisdictional differences in corporate governance, La Porta et al.'s (1997, 1998) maps of finance have assumed greater significance in setting expectations about past, present, and future practice.

The crisis of confidence in corporate governance has been one element driving the expanding range of metrics used to judge corporate performance. Perhaps just as important, has been the response of institutional investors to increasing pressure to be responsible investors in the sense of actively voting their proxies in annual general meetings. If this appears to be an issue only relevant to the Anglo-American world, we should take care not to underestimate the growing interest of continental European regulators in encouraging such notions of responsibility. In effect, as portfolio investors have moved on to the rest of the world they have also carried with them the responsibility to act in other jurisdictions in ways that go beyond simple entry and exit strategies. Responsibility is sometimes assessed against corporations in their home jurisdictions with respect to their actions in other jurisdictions. At the same time, experience with voting proxies in the United States has encouraged foreign institutional investors to look again at related practices in their home jurisdictions. Inevitably, given the range of the issues now considered in annual general meetings, more information is needed than might be found in the disclosure documents of the companies concerned. This has prompted the development of ratings companies that specialise in assessing these issues of corporate social responsibility and providing informed judgment as to the proper course of action.

Of significance, have been the attempts of investor activists to use annual general meetings to hold companies to account for their actions in Third World jurisdictions. Here, coalitions of institutional investors have provided activists a platform to raise searching questions about the environmental and social standards used by companies where legislative frameworks are poor or non-existent. The language of finance as inherited from the portfolio investment is silent on these issues (even hostile to raising these issues). Here again, measuring performance, providing justifiable metrics by which to judge performance, and assessing performance against accepted and justifiable environmental and social reference points have prompted institutional investors to seek third-party providers of those metrics (Clark and Hebb 2005). As consequence, there is a market for a broad range of global metrics, and those metrics must efficient markets hypothesis. 
be certified. By contrast, more often than not, there is little in the way of agreed robust "public" standards through which to judge these issues.

The political economy of global finance is driven, in part, by the search for standards by which to judge investment performance. But investment performance is increasingly a political issue as well as issue of risk-adjusted rates of return. Our observation, in this regard, is relatively straightforward: as the language of finance has lost its hegemony in the aftermath of that TMT bubble and the crisis of confidence in corporate governance, issues once excluded are now coming back to take centre-stage in debate over corporate responsibility. All this requires measurement for management (Lowenstein 1996). But it also requires a form of measurement that goes well-beyond market prices and the conventional techniques associated with portfolio investment management.

\section{Implications and conclusions}

Modern portfolio theory is widely acclaimed as the most important innovation in finance theory over the twentieth-century (Bernstein 1992). It provides a rationale for diversifying risk through spreading investment across a broad range of market securities. It provides a model for option pricing with many sophisticated versions developed over the past 25 years. It also provides a recipe for public policy especially as regards to enhancing the quality and quantity of information on traded securities such that market pricing is more efficient. On these grounds alone, it became the language of finance squeezing out traditional forms of investment as well as challenging models of industrial organisation that privilege insiders over outsiders. For some, it threatens the very future of continental European inherited systems of accumulation and income distribution. For others, it is thoroughly modern and a normative reference point for the future-where economic agents whatever their "home" jurisdictions will converge on the most efficient form of economic and social organisation.

Being a recipe for investment, the language of finance relies very heavily upon the quality and quantity of information provided to market agents. The quality of information could be characterised in terms of consistency, comparability, and continuity: consistency in that information by category is presented in ways that allow for summation and scoring; comparability in that information allows for the direct comparison between firms whatever their industries or jurisdictions; and continuity in that information is referenced to stable criteria such that market agents can look backwards and forwards over time. Market 
expectations are all about making judgments about current circumstances in relation to prospective opportunities. Similarly, the quantity of information refers to its comprehensiveness covering the relevant firms, markets, and issues judged crucial in making investment decisions. The public and private rules and regulations regarding the disclosure of information have fostered the efficiency of Anglo-American markets.

For some, more information is necessarily good. Likewise, improving the consistency, compatibility, and continuity of information adds value to investment decision-making. But information processing costs money. Indeed, it could be argued that one comparative advantage of institutional investors over individual investors is the capacity of the former to process information in ways that can uncover arbitrage opportunities hidden from individuals who have neither the computing power nor the analytical tools to make sense of the available data. More importantly, information need not lead market pricing but be a form of ex-post rationalisation which explains how and why an investment strategy may have succeeded or failed. We must take care not to idealise investment strategy as if it is and is always led by information as opposed to being subject to information channelling according to institutional imperatives. Finally, as information reflects past, current, and expected events, information must be valued. And the most obvious point of reference in valuing information is a theoretical conception of market performance.

However, this was precisely the problem revealed by the TMT bubble and the crisis of confidence in corporate governance. Not only are markets different from one another in terms of their underlying political economies, for all the arguments in favour of convergence to one ideal form of the market economic and political interests remain embedded in those markets such that adaptation is the more likely response rather than wholesale structural change (Sassen 2004). This is apparent in the cross-listing of firms from one market to another. It is also reflected in the geographical inertia of some types of market agents compared to others. In any event, markets are quite unstable over time in terms of the motive forces or imperatives driving market trading. Therefore, information maybe more or less relevant for trade between different markets, and more or less relevant overtime for trade within markets. Interjurisdictional differences in market structure combined with unanticipated shifts in marketspecific sentiment are likely to mean that disclosure is always less than optimal and is always being "reformed" in relation to past failings. 
We have argued in this paper that the language of finance has given way over the past few years to a more complex and empirically based investment practice. While it remains as a test of legitimacy for any investment professional, it is widely acknowledged to be at once too abstract and at another level too often exclusive of market relevant actions and sentiments (Shleifer 2000). At the limit, it supposes that it is virtually impossible to make money as an active investor. At the limit, it also suggests that there is only one kind of market wherein fact other kinds of markets have persisted even if challenged by the power and influence of Anglo-American markets. If quietly developed in the shadow cast by the language of finance, in the aftermath of the TMT bubble these new approaches to investment management have come out into the open. Using information asymmetries between market agents who have access to nominally the same information is an important element in market arbitrage. Likewise, being fleet-of foot in relation to unpredictable and unanticipated shocks has become one response to the apparent difficulties of sustaining superior performance.

Recognising these trends, there is a burgeoning market for third party information processing and valuation. There are many kinds of service providers in this market, some of which focus upon quantitative scoring while others focus upon qualitative assessment. In between, there are all kinds of ways of combining qualitative and quantitative information such that institutional investors' interests in tailored information products can be met. By this logic, the rules and regulations governing information disclosure simply set the stage for market agents that specialize in information processing rather than representing sufficient quality for market agents to trade in their own right. If so, national and international accounting standards relevant to financial markets may have a public benefit but be much less than that required for market agents to be competitive. By this logic, as the language of finance crumbles into an immense array of investment strategies, information itself will become increasingly variegated and private. Ironically, institutional investors may use their market power to claim the privileges accorded "insiders" of an earlier era.

Whatever the virtues of public information in public securities markets, market advantage is to be had in keeping private investment strategy and the information upon which it is based. In this context, independent ratings companies with well- developed databases covering issues and information unavailable to the public are increasingly one source of comparative advantage. It seems inevitable, then, that an aggressive takeover and acquisition market will 
develop bringing into the bulge-bracket investment houses the global metrics necessary to sustain their hold over market position and trading. 


\section{References}

Allen, F. and D. Gale (2000) Comparing Financial Systems. Cambridge MA: MIT Press

Ambachtsheer, K. (2004) Our 60/40 asset mix policy advice in 1987: wise or foolish? Letter 227. Toronto: KPA Advisory Services

Amin, A. (Ed.) (1994) Post-fordism: A Reader. Oxford: Blackwell

Arnott, R. D. (2004) Is our industry intellectually lazy? Financial Analysts Journal 60(1):6-8

Baumol, W. (2002) The Free-Market Innovation Machine. Princeton: Princeton University Press

Bernstein, P. L. (1992) Capital Ideas: The Improbable Origins of Modern Wall Street. New York: Free Press

Beunza, M. and D. Stark (2004) How to recognize opportunities: heterarchical search in a trading room. In The Sociology of Finance edited by K. Knorr Cetina and A. Preda. Oxford: Oxford University Press, pp. 84-101

Cable, V. (1999) Globalization and Global Governance. London: Royal Institute of International Affairs

Campbell, J. and L. Viceira (2002) Strategic Asset Allocation. Oxford: Oxford University Press

Chandler, A. (1990) Scale and Scope: The Dynamics of Industrial Capitalism. Cambridge MA: Harvard University Press

Chan-Lau, J. (2004) Pension funds and emerging markets. WP/04/181. Washington DC: International Monetary Fund

Clark, G. L. (2000) Pension Fund Capitalism. Oxford: Oxford University Press

Clark, G. L. (2003a) European Pensions \& Global Finance. Oxford: Oxford University Press

Clark, G. L. (2003b) Comment on Engelen: the European model is unsustainable. Environment and Planning A 35:1373-1376

Clark, G. L. (2005) Pension fund governance: models of regulation and accountability. In The Oxford Handbook of Pensions and Retirement Income edited by G. L. Clark, A, Munnell, and M. Orszag. Oxford: Oxford University Press (forthcoming)

Clark, G. L. and T. Hebb. (2004) Corporate engagement: The fifth stage of capitalism. Relations Industrielles/Industrial Relations 59:142-69

Clark, G. L. and T. Hebb. (2005) Why should they care? Politics and Society (forthcoming) Clark, G. L. and N. J. Thrift. (2004) The return of bureaucracy: managing dispersed knowledge in global finance. In The Sociology of Financial Markets edited by K Knorr Cetina and A. Preda. Oxford: Oxford University Press, pp. 229-249 
Clark, G. L., N. J. Thrift, and A. Tickell. (2004) Performing finance: the industry, the media, and its image. Review of International Political Economy 11:289-310

Clark, G. L. and D. Wójcik. (2003) An economic geography of global finance: ownership concentration and stock price volatility in German firms and regions. Annals, Association of American Geographers 93:909-24

Clark, G. L. and D. Wójcik. (2005a) Path dependence and the alchemy of finance: the economic geography of the German model, 1997-2003. Environment and Planning A (forthcoming)

Clark, G. L. and D. Wójcik. (2005b) Financial aspects of the German (regional) model. Economic Geography (forthcoming)

Clowes, M. (2000) The Money Flood: How Pension Funds Revolutionized Investing. New York: Wiley

Coffee, J. C. (2003) What caused Enron? A capsule social and economic history over the 1990s. Available at ssrn.com (abstract 373581)

Dale, R. (2004) The First Crash: Lessons from the South Sea Bubble. Princeton: Princeton University Press

Davis, E. P. and B. Steil. (2001) Institutional Investors. Cambridge MA: MIT Press

Davis, P. and Y-W. Hu. (2005) Saving, funding and economic growth. In The Oxford Handbook of Pensions and Retirement Income edited by G. L. Clark, A, Munnell, and M. Orszag. Oxford: Oxford University Press (forthcoming)

Dimson, E., P. Marsh and M. Staunton. (2002) Triumph of the Optimists. Princeton: Princeton University Press

Dore, R. (2000) Stock Market Capitalism: Welfare Capitalism. Japan and Germany versus the Anglo-Saxons. Oxford: Oxford University Press

Drucker, P. (1997) The Pension Fund Revolution. Piscataway: Transaction Books

Engelen, E. (2003) The logic of funding European pension restructuring and the dangers of financialisation. Environment and Planning A 35:1357-1372

Fama, E. (1970) Efficient capital markets: a review of theory and empirical work. Journal of Finance 25:383-417

Fama, E. and K. R. French. (2004) The capital asset pricing model: theory and evidence. Journal of Financial Economics (forthcoming)

Gordon, J. N. (1987) The puzzling persistence of the "constrained prudent man rule. New York University Law Review 62:52-114 
Gordon, J. N. (2003) Governance failures of the Enron board and the new information order of Sarbanes-Oxley, Working Paper 416. Cambridge MA: J.M. Olin Center for Law, Business and Economics, Harvard University

Hall, P. A. and D. Soskice. (Eds.) (2001) Varieties of Capitalism: The Institutional Foundations of Comparative Advantage. Oxford: Oxford University Press

Hawley, J. P. and A. T. Williams. (2000) The Rise of Fiduciary Capitalism. Philadelphia: University of Pennsylvania Press

Hayes, S. L. (Ed.) (1993) Financial Services: Perspectives and Challenges. Boston: Harvard Business School Press

Hebb, T. and D. Wójcik. (2005) The institutional investment value chain: CalPERS' emerging markets strategy. Environment and Planning A (forthcoming).

Hilton, D. J. (2003) Psychology and the financial markets: applications to understanding and remediating investment decision-making. In The Psychology of Economic Decisions. Volume 1: Rationality and Well-Being edited by I. Brocas and J. Carrillo. Cambridge: Cambridge University Press, pp. 273-297

Ho, T. and S. B. Lee. (2004) The Oxford Guide to Financial Modeling. Oxford: Oxford University Press

Hopt, K. J. and others (Eds.) (1998) Comparative Corporate Governance: The State-of-theArt and Emerging Research. Oxford: Oxford University Press

Houthakker, H. and P. J. Williamson. (1996) The Economics of Financial Markets. Oxford: Oxford University Press

Jameson, F. (1997) Culture and finance capital. Critical Inquiry 24:246-265

Jensen, M. (1993) The modern industrial revolution, exit, and the failure of internal control systems. Journal of Finance 48:831-880

La Porta, R., F. Lopez-De-Silanes, A. Shleifer, and R. W. Vishny. (1997) Legal determinants of external finance. Journal of Finance 52:1131-50

La Porta, R., F. Lopez-De-Silanes, A. Shleifer, and R. W. Vishny. (1998) Law and finance. Journal of Political Economy 106:1113-55

Litterman, B. et al. (2003) Modern Investment Management. New York: Wiley

Lo, A. (2004) The adaptive markets hypothesis: market efficiency from an evolutionary perspective. Cambridge MA: Laboratory for Financial Engineering, MIT

Lowenstein, L. (1996) Financial transparency and corporate governance: you manage what you measure. Columbia Law Review 96:1335-62

Markowitz, H. M. (1952) Portfolio selection. Journal of Finance 7:77-91 
O'Sullivan, M. (2000) Contests for Corporate Control: Corporate Governance and Economic Performance in the United States and Germany. Oxford: Oxford University Press

Pettit, P. (2002) Rules, Reasons, and Norms. Oxford: Oxford University Press

Power, M. (2004) Enterprise risk management and the organization of uncertainty in financial firms. In The Sociology of Finance edited by K. Knorr Cetina and A. Preda. Oxford: Oxford University Press, pp. 250-268

Roe, M. J. (1994) Strong Managers, Weak Owners: The Political Roots of American Corporate Finance. Princeton: Princeton University Press

Roy, A. D. (1950) Safety first and the holding of financial assets. Econometrica 20:431-449

Salo, J. (2005) Ratings agencies in the global market for social and environmental standards. WPG 05-02. Oxford: School of Geography and the Environment, University of Oxford Sarno, L. and M. P. Taylor. (2002) The Economics of Exchange Rates. Cambridge: Cambridge University Press

Sassen, S. (2004) The embeddedness of electronic markets: the case of global capital markets. In The Sociology of Finance edited by K. Knorr Cetina and A. Preda. Oxford: Oxford University Press, pp. 17-37

Shiller, R.J. (2000) Irrational Exuberance. Princeton: Princeton University Press

Shiller, R. J. (2003) The New Financial Order. Princeton: Princeton University Press

Shleifer, A. (2000) Market Inefficiency. Oxford: Oxford University Press

Webber, M. J. and D. L. Rigby. (1996) The Golden Age Illusion: Rethinking Postwar

Capitalism. New York: Guilford

Wilhelm, W. J. and Downing, J. D. (2001) Information Markets. Boston MA: Harvard Business School Press

Wilson, D. and R. Purushothaman. (2003) Dreaming with the BRICs: The Path to 2050. Global Economics Paper 99. New York: Goldman Sachs

Wójcik, D. (2003) Change in the German model of corporate governance: evidence from blockholdings 1997-2001. Environment and Planning A 35:1431-1458

Wójcik, D. (2004) Convergence in corporate governance: empirical evidence from Europe 2000-2003. WPG 04-19. Oxford: School of Geography and the Environment, University of Oxford

Wójcik, D., Clark, G. L., and Bauer, R. (2004) Corporate governance and cross-listing: evidence from European companies. WPG 04-24. Oxford: School of Geography and the Environment, University of Oxford

Zingales, L. (2000) In search of new foundations. Journal of Finance 55:1623-53 
Zion, D. (2004) Expensing Stock Options. Report. New York: Credit Suisse First Boston Zorn, D., F. Dobbin, J. Dierkes, and M-S. Kwok. (2004) Managing investors: how financial markets reshaped the American firm. In The Sociology of Finance edited by K. Knorr Cetina and A. Preda. Oxford: Oxford University Press, pp. 269-289 
Table 1. Pension funds assets under management in selected markets (US\$ billion)

\begin{tabular}{|c|c|c|c|c|c|c|c|c|}
\hline & & 1990 & 1992 & 1994 & 1996 & 1998 & 2000 & 2001 \\
\hline Canada & $\begin{array}{l}\text { AUM } \\
\text { percent of GDP }\end{array}$ & $\begin{array}{l}169.8 \\
29.0\end{array}$ & $\begin{array}{l}184.5 \\
33.5\end{array}$ & $\begin{array}{l}207.2 \\
37.7\end{array}$ & $\begin{array}{c}254.9 \\
41.7\end{array}$ & $\begin{array}{c}283.7 \\
47.5\end{array}$ & $\begin{array}{c}342.6 \\
48.3\end{array}$ & $\begin{array}{c}330.9 \\
48.2\end{array}$ \\
\hline Japan & $\begin{array}{l}\text { AUM } \\
\text { percent of GDP }\end{array}$ & $\begin{array}{c}407.9 \\
12.4\end{array}$ & $\begin{array}{c}477.9 \\
12.4\end{array}$ & $\begin{array}{c}672.4 \\
13.6\end{array}$ & $\begin{array}{c}663.3 \\
15.0\end{array}$ & $\begin{array}{c}722.2 \\
16.2\end{array}$ & $\begin{array}{c}825.8 \\
18.5\end{array}$ & $\begin{array}{c}710.7 \\
18.5\end{array}$ \\
\hline $\begin{array}{l}\text { United } \\
\text { Kingdom }\end{array}$ & $\begin{array}{l}\text { AUM } \\
\text { percent of GDP }\end{array}$ & $\begin{array}{c}536.6 \\
49.9\end{array}$ & $\begin{array}{c}552.4 \\
59.8\end{array}$ & $\begin{array}{c}660.5 \\
62.0\end{array}$ & $\begin{array}{c}893.2 \\
69.0\end{array}$ & $\begin{array}{c}1136.5 \\
79.3\end{array}$ & $\begin{array}{c}1116.3 \\
78.7\end{array}$ & $\begin{array}{c}954.0 \\
66.4\end{array}$ \\
\hline $\begin{array}{l}\text { United } \\
\text { States }\end{array}$ & $\begin{array}{l}\text { AUM } \\
\text { percent of GDP }\end{array}$ & $\begin{array}{c}2435.1 \\
42.0\end{array}$ & $\begin{array}{c}3011.6 \\
47.7\end{array}$ & $\begin{array}{c}3547.9 \\
50.3\end{array}$ & $\begin{array}{c}4745.7 \\
60.7\end{array}$ & $\begin{array}{c}6231.3 \\
71.0\end{array}$ & $\begin{array}{c}6805.0 \\
69.3\end{array}$ & $\begin{array}{c}6351.3 \\
63.0\end{array}$ \\
\hline Total & $\begin{array}{l}\text { AUM } \\
\text { percent of GDP }\end{array}$ & $\begin{array}{c}3736.8 \\
27.2\end{array}$ & $\begin{array}{c}4433.6 \\
30.3\end{array}$ & $\begin{array}{c}5298.3 \\
31.5\end{array}$ & $\begin{array}{c}6792.8 \\
38.4\end{array}$ & $\begin{array}{c}8631.5 \\
46.0\end{array}$ & $\begin{array}{c}9353.9 \\
48.3\end{array}$ & $\begin{array}{c}8595.6 \\
45.3\end{array}$ \\
\hline
\end{tabular}

Source: Chan-Lau (2004) 